NBER WORKING PAPER SERIES

\title{
PRIVATE PENSIONS, MORTALITY RISK, AND THE DECISION TO ANNUITIZE
}

Jeffrey R. Brown

Working Paper 7191

http://www.nber.org/papers/w7191

\author{
NATIONAL BUREAU OF ECONOMIC RESEARCH \\ 1050 Massachusetts Avenue \\ Cambridge, MA 02138 \\ June 1999
}

The author thanks Courtney Coile, Peter Diamond, Bill Even, Jon Gruber, Jerry Hausman, Olivia Mitchell, Sendhil Mullainathan, Mark Warshawsky, Scott Weisbenner, and especially James Poterba for helpful discussions. Helpful comments were also received from seminar participants at MIT, the Kennedy School, Miami University, the University of Maryland, Georgia State's Risk Management and Insurance Department, TIAA-CREF, and Williams College. Financial support from the National Science Foundation and the Aging Program of the National Bureau of Economic Research / National Institute on Aging is gratefully acknowledged. All opinions expressed are those of the authors and not those of the National Bureau of Economic Research.

(C) 1999 by Jeffrey R. Brown. All rights reserved. Short sections of text, not to exceed two paragraphs, may be quoted without explicit permission provided that full credit, including $\mathcal{C}$ notice, is given to the source. 
Private Pensions, Mortality Risk, and the Decision to Annuitize

Jeffrey R. Brown

NBER Working Paper No. 7191

June 1999

JEL No. J26, J14, H55

\begin{abstract}
This paper examines household decisions about whether or not to annuitize retirement resources. A life-cycle model of consumption, implemented with the use of dynamic programming techniques, is used to construct a utility-based measure of annuity value for individuals and couples in the Health and Retirement Survey. Variation in the calculated "annuity equivalent wealth" arises from differences in mortality risk, marital status, risk aversion, and the presence of pre-existing annuities such as Social Security. I find that a one-percentage point increase in the annuity equivalent wealth leads to nearly a one-percentage point increase in the ex ante probability of annuitizing balances in defined contribution pension plans. However, because much of the variation in the expected annuity decision is left unexplained by the life-cycle model, other factors are also analyzed. Health status and an individual's time horizon for financial decision making are significant determinants of the decision. There is no evidence that bequest motives are an important factor in making marginal annuity decisions.
\end{abstract}

\title{
Jeffrey R. Brown
}

Kennedy School of Government

Harvard University

79 John F. Kennedy St.

Cambridge, MA 02138

and NBER

brown@nber.org 


\section{Introduction}

It is an established empirical fact that very few individuals purchase life annuities in the United States. Why this is the case has long been a puzzle to economists. Annuities should be of substantial value to risk averse individuals in a life-cycle model with uncertain lifetimes. Despite the large literature that explores possible resolutions of this puzzle, surprisingly little direct empirical evidence exists to guide our understanding of who annuitizes, and what factors influence this decision. Reconciling the theory with such empirical evidence is essential to understanding the annuity puzzle.

The primary contribution of this paper is to use micro data to directly examine household decisions about whether or not to annuitize balances in defined contribution pension plans. A central goal is to test whether or not this annuitization decision is consistent with the stochastic life-cycle model that economists commonly use to study annuitization decisions. Using dynamic

programming techniques, I construct a utility-based measure of a life-cycle consumer's valuation of additional annuitization, or the "annuity equivalent wealth" (AEW). This measure varies across households based on mortality, risk aversion, marital status, and the presence of preexisting annuity flows from Social Security. I then ask whether this single annuity equivalent wealth measure can explain annuitization intentions, as the life-cycle model suggests it should. The results indicate that this calculated measure of annuity value is significantly correlated with expected annuitization decisions.

Whether or not households choose to annuitize their retirement assets has a number of important economic implications. First and foremost, it has a direct effect on how well prepared individuals are to provide for consumption in old age. Adequacy of resources for old-age consumption in turn directly affects the extent of poverty among elderly widows, and the 
financial pressure placed on needs-based social insurance programs for the elderly such as SSI and Medicaid. Second, households who annuitize their assets will not leave these resources to their heirs when they die. Thus, the extent of annuitization can potentially affect the aggregate amount of intergenerational transfers taking place in the economy, the distribution of wealth in the younger generation of inheritors, and even the amount of estate tax revenue collected.

There are at least two reasons that these questions are becoming ever more important. First, the past 25 years has witnessed a dramatic shift in the composition of private pension plans away from traditional defined benefit plans, which typically paid out in the form of a life annuity, towards defined contribution plans, which offer the individual choice over the form of the benefit payment. This trend towards increased importance of DC plans is expected to continue. For example, by the year 2025 the average value of $401(\mathrm{k})$ plan assets is expected to rival the present discounted value of Social Security benefits (Poterba, Venti, \& Wise 1998).

Second, the current debate over the future of Social Security has spawned a number of proposals that would create a system of mandatory individual savings accounts as a supplement to or partial substitute for the current annuitized system. One of the key issues in this debate is whether or not to mandate annuitization of these individual account balances. An examination of current behavior with respect to DC pension plans is a starting point for understanding how individuals might respond to such a system.

The results of this paper indicate that the utility-based measure of annuity equivalent wealth (AEW) that is constructed from a stochastic life-cycle model is significantly positively correlated with the ex ante probability of actually annuitizing DC balances. Specifically, a onepercentage point increase in the calculated annuity equivalent wealth is associated with nearly a one percentage-point increase in the probability that an individual before retirement reports that 
they will annuitize. This effect is highly significant, and robust to many specific modeling assumptions and to the inclusion of a wide range of covariates.

This finding, that the predictions of the life-cycle model are in fact correlated with expected behavior, provides empirical support for many previous studies. Some version of the life-cycle model has been used in nearly every simulation study of annuity demand (for example: Kotlikoff \& Spivak 1981, Friedman \& Warshawsky 1988, Mitchell et al 1999), yet there has been no prior empirical evidence supporting the use of this model for analyzing annuity choices. The ability of the life-cycle model to predict economic behavior has been questioned in a number of contexts, such as savings behavior (Thaler 1991). This study represents the first evidence that the predictions of the life-cycle model regarding annuity behavior are in fact correlated with the outcome of interest.

However, these results also indicate that while the predictions of the life-cycle model are a good "first approximation" to expected behavior, the model leaves much variation unexplained. There are a number of factors which are difficult to incorporate directly into the calculated annuity equivalent wealth measure that are significant determinants of the annuity decision, such as poor health status. Importantly, one factor that is found not to have a significant effect is the presence of bequest motives. This result is consistent with Hurd's (1986) finding that bequest motives do not influence wealth decumulation patterns of the elderly. I also find that there is a subset of the population, those with self-reported short time horizons for financial decision making, for whom the predictions of the life-cycle model do not predict annuity decisions.

This paper is organized as follows: Background information on DC pension plans is described in Section 2. The predictions of the simple life-cycle model with uncertain lifetimes are discussed in Section 3, along with a discussion of the model's limitations. Section 4 explains 
the methodology for implementing the life-cycle measure of annuity valuation. The data set used, sample selection, and the parameterization of the model are discussed in Section 5. Results are presented and discussed in Sections $6 \& 7$. Section 8 concludes.

\section{Recent Growth in Defined Contribution Plans}

Over the past 25 years, the pension landscape in the U.S. has altered dramatically. The 1974 enactment of the Employee Retirement Income Security Act (ERISA) signaled a dramatic change in the regulation and oversight of private pensions in the U.S. This was followed by the introduction of 401(k) plans in 1978, as well as 1981 clarifying regulations that sparked a dramatic increase in 401(k) plan availability and participation.

This change in the legal environment, and the increasing administrative costs that these changes induced for defined benefit plans (McGill, et al 1996), have contributed to making defined contribution plans an increasingly important source of retirement resources. Between 1975 and 1993, the number of private defined contribution plans in existence nearly tripled, rising from 208,000 to 619,000 . Meanwhile, the number of defined benefit plans peaked at 175,000 in 1983 , and then fell $52 \%$ to only 84,000 plans in 1993. (EBRI, 1997). As a result, by 1993, defined contribution plans made up $88 \%$ of outstanding plans.

Through the 1980s, however, defined benefit plans continued to cover more participants than DC plans. In 1975, 74\% of plan participants were covered by DB plans. By 1993, however, over half (52\%) of pension plan participants were covered by DC plans. Barring any

future legislative changes that would reverse this trend, DC plans promise to continue to grow in relative importance in the coming years. 
A large part of this growth came in the form of 401(k) plan participation. Over the tenyear period from 1984 to 1993, the number of participants in private-sector qualified 401(k) plans rose from 7.5 million to 23.1 million. (EBRI, 1997) In 1991, 35\% of those age 65-69 held assets in targeted retirement savings accounts. By the year 2025, assets in 401(k) plans are expected to be $90 \%$ as large as the present discounted value of Social Security assets. (Poterba, Venti \& Wise, 1998).

DC plan distributions at retirement typically may take the form of lump-sum payments, installment payments, or a life annuity. Most plans allow participants some choice over the form of the distribution. This is in sharp contrast to DB plans, the majority of which do not permit lump-sum distributions at retirement. According to Watson-Wyatt, only $29 \%$ of DB plans permit an unlimited lump-sum payment in lieu of an annuitized pension at retirement, with another $8 \%$ allowing a partial lump-sum. (McGill, 1996). Many DB plan sponsors discourage lump-sum distributions at retirement to limit exposure to adverse selection, and/or to ensure that employees do not squander or outlive their pension resources.

In the sub-sample of the Health and Retirement Survey that I will use in my analysis, $48 \%$ of households expect to annuitize at least some portion of their defined contribution account balances. This is consistent with the aggregate numbers of individuals who appear to be annuitizing DC balances according to the Current Population Survey. In September, 1994, the CPS included a health and pension benefits supplement that asked a limited number of questions about pension coverage among the age $40+$ population. For a number of reasons, it is not possible to construct a precise estimate of the annuity decisions of all individuals with defined contribution plans. Nonetheless, one can get a rough estimate of DC pension choice from the supplement by constructing a sample of anyone who is currently receiving their largest or only 
annuity from a DC plan, or who has ever received a lump-sum distribution from a DC plan. Among the individuals age 65-75 in this sample, most of whom are already retired, 53\% are receiving a life annuity from a DC plan.

\section{Theory: A Life-Cycle Model with Uncertain Lifetimes}

\subsection{The Basic Yaari Model}

Yaari's classic 1965 article was the first to incorporate a random date of death into a life cycle framework. He considered the problem of an individual, facing a known probability distribution over the length of life, determining how to optimally consume out of a given stock of wealth. Yaari worked through the problem with and without bequest motives, and with and without access to actuarially fair markets for annuities.

The most well-known result of this work is the finding that:

"when the consumer has no bequest motive but he is constrained to meet the requirement that his transferable assets at time of death should be non-negative with probability one ... the consumer's assets will always be held in actuarial notes rather than in regular notes."

In other words, a life-cycle consumer with no bequest motives will always choose to annuitize $100 \%$, provided that the market for annuities is actuarially fair. The intuition for this result is clear. A consumer can choose to hold assets either as ordinary notes which pay the market rate of interest $r$, or as actuarial notes, which pay the market interest rate $r$ plus a "mortality premium" equal to the mortality hazard rate. The "cost" of this higher return is that the actuarial notes, or annuities, are cancelled upon his death. In the case where the life-cycle consumer places no value on wealth after death, i.e., he has no bequest motives, then the "cost" of annuities is zero, and the individual will always prefer to invest in the higher yielding actuarial notes. 
Previous simulation work has shown that the gains to annuitization in the simple Yaari model without bequest motives are significant. For example, a 65 year old male facing with population average mortality would be willing to give up roughly $1 / 3$ of his wealth to gain access to an actuarially fair annuity market according to this simple Yaari life-cycle model. The gains to annuitization for couples tend to be on order of half that of individuals due to opportunities for mortality risk-sharing within families.

\subsection{The Annuity Puzzle}

The stylized result of the Yaari model, that individuals without bequest motives will fully annuitize their wealth, is clearly not borne out in the data. Aside from Social Security and private pensions, very few Americans annuitize much of their net worth. For example, Moore \& Mitchell (1998) found in the Health and Retirement Survey that $40 \%$ of total wealth was held in Social Security and another $20 \%$ in private pensions. This leaves an additional $40 \%$ of total wealth being held in traditional financial assets and/or housing. Further, the non-pension annuity market in the U.S. is quite small, with single premium immediate annuity (SPIA) products accounting for only a few billion dollars (LIMRA, 1998).

This has led a number of researchers to search for solutions to the "annuity puzzle" in the U.S. Among the explanations explored are a role for bequest motives (Bernheim 1991, Abel \& Warshawsky 1988), the role of adverse selection and administrative load factors (Friedman \& Warshawsky 1988, Mitchell, et al 1999), and the ability of families to pool risk and thus substitute for a private annuity market (Brown \& Poterba 1999, Kotlikoff \& Spivak 1981).

\section{$\underline{\text { 3.3 Annuity Demand with Load Factors }}$}

It is easy to see why the presence of a load factor would diminish the demand for annuities. Recall that for an individual without bequest motives, part of the value of an 
actuarially fair annuity arises from the fact that the rate of return on an annuity is higher than that on ordinary bonds. This mortality premium arises from the fact that the assets from deceased annuitants are paid out to surviving annuitants.

There are two types of load factors that can diminish the value of annuitization, however. The first is a pure "administrative" load cost, i.e., some fraction of the premium that the insurance company takes "off the top" to cover administrative expenses and accounting profits. If the load factor is high enough to offset the benefits of annuitization, a rational life-cycle individual will choose not to purchase annuities.

The second type of load factor arises from the heterogeneity in survival probabilities in the population. The expected discounted value of annuity benefits will vary across individuals in accordance with differences in their survival probabilities. Roughly speaking, individuals with longer life expectancies can expect more benefits than individuals with shorter life expectancies. ${ }^{1}$ Insurance companies must take this potential adverse selection into account when pricing annuities, which has the effect of decreasing the level of the monthly annuity payout that is offered for a given premium.

Mitchell, et al, (1999) found that the expected net present value of a single premium immediate life annuity for a 65 year old male in 1995 was approximately $80 \%$ of the required premium. By using the difference between the population mortality table, and the mortality table used by insurance companies to represent the mortality experience of the annuitized population, one is able to partially disentangle these two types of load factors. Using this method, we attributed approximately one-half of this premium, or approximately $10 \%$, to mortality differences between annuitants and non-annuitants, and the other half to administrative costs of

\footnotetext{
${ }^{1}$ Strictly speaking, it is the entire trajectory of mortality probabilities, not just the life expectancy, which matters.
} 
the insurance industry. Clearly, load factors are one reason that individuals may choose not to annuitize their resources.

\section{Methodology: Implementing the Yaari Model}

\subsection{Methodological Overview}

The simple Yaari life-cycle model without load factors, bequests, or other non-mortality sources of uncertainty indicates that everyone will have an annuity equivalent wealth that is nonnegative. The magnitude of this annuity equivalent wealth, however, may vary greatly across individuals based on the behavioral and economic parameters that we assume. For example, more risk averse individuals will have a higher valuation of annuities than less risk averse individuals. Annuity value should also be decreasing with the amount of wealth that is already previously annuitized by Social Security and DB pension plans. Other factors, such as marital status (which captures opportunities for within-family risk sharing) and age at retirement should also effect the demand for annuities.

One econometric approach would be to simply model the annuity decision as a direct function of these variables. However, the Yaari life-cycle model imposes a specific structure on these effects, and also allows more readily for the potentially complicated interactions between these parameters. For example, the effect of a difference in marital status will likely differ in magnitude for individuals with different levels of risk aversion. Therefore, this section develops a dynamic programming algorithm which feeds these behavioral and economic variables through a utility maximizing framework, in order to construct an "annuity equivalent wealth" (AEW) measure that is consistent with the underlying utility theory of a life-cycle consumer. 
This AEW approach is directly related to methods of annuity valuation that have been used in simulation models in previous work by several authors (Kotlikoff \& Spivak 1981, Friedman \& Warshawsky 1988, Mitchell, et al 1999). The primary contribution of this paper is to move beyond simple simulations for hypothetical consumers and estimate the AEW measure for a sample of actual households in the Health and Retirement Survey. I will use HRS data whenever possible to choose parameter values for each individual, thus capturing much of the heterogeneity in annuity values within the HRS population.

\subsection{Calculating the Annuity Equivalent Wealth}

The annuity equivalent wealth calculation proceeds in 2 basic steps. In all cases, an individual is assumed to be solving an expected utility maximization problem, subject to budget constraints that depend on whether or not annuities are available. In the first step, the individual is assumed to have access to actuarially fair, real annuity markets that enable her to fully annuitize her starting wealth $\mathrm{W}_{0}$. The individual chooses a consumption path to maximize utility, subject to non-negativity constraints on wealth in every period. Let this maximum utility level be denoted $\mathrm{U}^{*}$. It is assumed that the individual does not value bequests.

The second step is to then take away access to the annuity market, and find the amount of additional wealth, $\Delta \mathrm{W}$, that must be given to her so that by following her optimal consumption path in the absence of annuitization, she can achieve utility level $\mathrm{U}^{*}$. The only investment opportunity the individual has in this case is riskless bonds. The amount $\left(\mathrm{W}_{0}+\Delta \mathrm{W}\right) / \mathrm{W}_{0}$ is the measure of annuity value that I will refer to as the "annuity equivalent wealth."

This utility-based measure of annuity equivalent wealth is similar to the Equivalent Variation measure in applied welfare analysis. The value $\Delta \mathrm{W}$ answers the question, "how much additional wealth must we give a person in the absence of annuitization to make them as well off 
(i.e., to put them on the same expected utility curve) as if we provided actuarially fair annuity markets for the individual." One could alternatively construct the annuity equivalent wealth measure in a manner analogous to Compensating Variation by using the non-annuity level of utility as the baseline for comparison.

More formally, solving for optimal consumption paths in this multi-period, stochastic life-cycle model requires the use of dynamic programming methods. Let $U\left(C_{t}\right)$ represent the one-period felicity function defined over real consumption, $\rho$ the utility discount rate, and $\mathrm{T}$ the maximum possible life-span of an individual (assumed to be 115). Then the consumer's problem, assuming additive separability over time, is:

$$
\operatorname{Max}_{\left\{C_{t}\right\}} E_{t}\left[\sum_{t=1}^{T-\text { age }+1} \frac{U\left(C_{t}\right)}{(1+\rho)^{t}}\right]
$$

where the expectation $E_{t}[$.$] is taken over states of survival, subject to the following constraints:$

$$
\begin{array}{ll}
(\text { i }) & W_{0} \text { given } \\
(\text { ii }) & W_{t} \geq 0, \forall t \\
(\text { iii }) & W_{t+1}=\left(W_{t}-C_{t}+S_{t}+A_{t}\right)(1+r)
\end{array}
$$

In these constraints, $W_{t}$ is non-annuitized wealth in period $t, C_{t}$ is consumption, $S_{t}$ is the pre-existing annuity payment from Social Security and DB pensions, and $A_{t}$ is the actuarially fair annuity payment that can be purchased when supplemental annuity markets are available. Assume that the individual, prior to any optional annuitization, has financial wealth $\mathrm{W}^{*}$. Then for the case in which no supplemental annuities are available, $\mathrm{W}_{0}=\mathrm{W}^{*}$, and $\mathrm{A}_{\mathrm{t}}=0, \forall \mathrm{t}$. In the case in which the individual fully annuitizes all financial assets, then $\mathrm{W}_{0}=0$, and $\mathrm{A}_{t}$ is determined by assuming that the expected discounted value of $A_{t}$ is equal to the initial premium $\left(\mathrm{W}^{*}\right)$ :

$$
W^{*}=\sum_{t=1}^{T-a g e+1} \frac{A_{t} \prod_{j=1}^{t}\left(1-q_{j}\right)}{(1+r)^{t}(1+\pi)^{t}}
$$


In equation (3), $\mathrm{q}_{\mathrm{t}}$ is the one-period mortality hazard, i.e., the probability of dying before period $t+1$ conditional on surviving to period $t$. The real interest rate is represented by $r$, and the inflation rate by $\pi$. Note that this formula determines the nominal value of a fixed nominal annuity. The real value of this annuity declines by the factor $1 /(1+\pi)$ each period. By setting $\pi=0$, equation (3) can be used to determine the starting value of a real annuity as well.

In order to use dynamic programming techniques, it is useful to introduce a value function $\mathrm{V}_{\mathrm{t}}\left(\mathrm{W}_{\mathrm{t}}\right)$, which is defined as:

$$
V_{t}\left(W_{t}\right)=\operatorname{Max}_{\left\{C_{t}\right\}} E_{t}\left[\sum_{t=1}^{T-a g e+1} \frac{U\left(C_{t}\right)}{(1+\rho)^{t}}\right]
$$

subject to the constraints in equation (2).

The value function at time $t$ is the present discounted value of expected utility evaluated along the optimal path. This value function satisfies the following recursive Bellman equation:

$$
\operatorname{Max}_{\left\{C_{t}\right\}} V_{t}\left(W_{t}\right)=\operatorname{Max}_{\left\{C_{t}\right\}} U\left(C_{t}\right)+\frac{\left(1-q_{t+1}\right)}{(1+\rho)} V_{t+1}\left(W_{t+1}\right)
$$

Note that the expectation operator has been dropped, as we are now accounting explicitly for the survival probabilities, and there are no other sources of uncertainty in this problem. The Bellman equation reduces the full maximization problem to a series of 2-period problems, which can be solved numerically by solving back from the final period. This maximization is subject to the constraints in equation (2). I use standard methods of discretizing the wealth space to closely approximate the solution. While in some special cases it is possible to derive a solution analytically, the presence of pre-existing annuities requires numerical methods in the more general case.

In addition to an amount of financial wealth $\mathrm{W}^{*}$, I assume that there is an exogenously determined path of pre-existing annuities $\left\{\mathrm{S}_{\mathrm{t}}\right\}$. I first find the maximum utility $\mathrm{V}^{*}$ for the case in 
which the individual has the ability to fully annuitize $\mathrm{W}^{*}$ in an actuarially fair, nominal annuity market, so that $A_{t}$ is determined by equation (3). Because this individual fully annuitizes, he starts off with zero non-annuitized wealth, $\mathrm{W}_{0}=0$.

I then solve the problem again for the case in which annuities are not available. That is, $A_{t}$ is constrained to be zero for all $t$. I find the amount of additional wealth, $\Delta \mathrm{W}$, which must be given to the individual in the absence of annuities such that the utility without annuities is equal to $\mathrm{V}^{*}$.

That is, I find $\Delta \mathrm{W}$ such that:

$$
\mathrm{V}\left(\mathrm{W}^{*}+\Delta \mathrm{W} \mid \mathrm{A}_{\mathrm{t}}=0, \forall \mathrm{t}\right)=\mathrm{V}^{*}
$$

Annuity equivalent wealth is then defined as:

$$
A E W=\frac{W^{*}+\Delta W}{W^{*}}
$$

This calculated AEW measure essentially captures the maximum markup over the actuarially fair cost that an individual would be willing to pay. Notice that this calculation assumes that all wealth is annuitized, as would be the case in a simple Yaari life-cycle model with no bequests.

In the case of married couples, the procedure is the same. However, the value function of the single individual is replaced by a more complicated function that represents the joint decision of the couple. I assume that the couple maximizes a joint utility function that is the weighted sum of the utility of the two individuals, while allowing for economies of scale in consumption. The Bellman equation for couples is: 


$$
\begin{aligned}
V_{t}\left(W_{t}\right)=\operatorname{Max}_{\left\{C_{t}^{m}, C_{t}^{f}\right\}} & U^{m}\left(C_{t}^{m}+\lambda C_{t}^{f}\right)+\psi U^{f}\left(C_{t}^{f}+\lambda C_{t}^{m}\right) \\
& +\frac{\left(1-q_{t+1}^{m}\right) q_{t+1}^{f}}{(1+\rho)} M_{t+1}\left(W_{t+1}\right)+\frac{\left(1-q_{t+1}^{f}\right) q_{t+1}^{m}}{(1+\rho)} F_{t+1}\left(W_{t+1}\right) \\
& +\frac{\left(1-q_{t+1}^{m}\right)\left(1-q_{t+1}^{f}\right)}{(1+\rho)} V_{t+1}\left(W_{t+1}\right)
\end{aligned}
$$

Here, V represents the value function for the couple, while M and F represent the value functions for the male and female for those states in which they are the surviving spouse. M and $\mathrm{F}$ are defined as in the individual case in equation 5. Superscripts " $\mathrm{m}$ " and " $\mathrm{f}$ " on the consumption and survival probability terms represent the male and the female, respectively. Once again, this maximization is subject to the constraints in equation 2, using the fact that $\mathrm{C}_{\mathrm{t}}=\mathrm{C}_{\mathrm{t}}^{\mathrm{m}}+\mathrm{C}_{\mathrm{t}}^{\mathrm{f}}$. Note that the parameter $\lambda$ determines the degree of economies of scale in consumption within a 2 -person household. When $\lambda=0$, there are no economies of scale. When $\lambda=1$, the economies of scale in consumption are complete. In this paper, I will assume that $\psi=1$ and $\mathrm{U}^{\mathrm{m}}()=.\mathrm{U}^{\mathrm{f}}($.$) . These two restrictions imply that the husband and the wife will consume equal$ amounts when alive.

In the case of couples, equation 3 is replaced with a more general annuity pricing equation for joint life annuities with survivor benefits. In order to simplify notation, let us first define $\mathrm{P}_{\mathrm{t}}^{\mathrm{m}}$ to be the cumulative probability of survival through time $\mathrm{t}$, that is:

$$
P_{t}^{m}=\prod_{j=1}^{t}\left(1-q_{j}^{m}\right)
$$

This is the probability that an individual alive at time 0 survives to time $t$. We can define $\mathrm{P}_{\mathrm{t}}^{\mathrm{f}}$ analogously. Then, assuming actuarial fairness, the pricing equation for a joint and survivor annuity is:

$$
W^{*}=\sum_{t=1}^{T-a g e+1} \frac{A_{t} P_{t}^{m} P_{t}^{f}+\theta A_{t}\left[P_{t}^{m}\left(1-P_{t}^{f}\right)+P_{t}^{f}\left(1-P_{t}^{m}\right)\right]}{(1+r)^{t}(1+\pi)^{t}}
$$


In this equation, the parameter $\theta$ represents the ratio of survivor benefit to the annuity flow when both members of the couple are alive. The most common values of $\theta$ in the private annuity markets are one-half, two-thirds, and one. For example, a "joint and half survivor" annuity that pays out $\$ 800$ per month when both spouses are alive, will pay out $\$ 400$ after the death of the first spouse. This equation assumes that spouses are treated symmetrically with regard to the survivor benefit. There is also a class of products known as "joint and contingent" annuities that distinguish between primary and secondary annuitants. With these products, the annuity only drops upon the death of the primary annuitant, not the secondary.

\section{The Data \& Parameterizing the Model}

\subsection{The HRS Sample}

The analysis of how individuals dispose of their DC account balances would ideally be based on a large data set of DC participants near retirement, and would follow them for many years to track the ultimate disposition of these resources. The multi-year time frame is potentially quite important, because many individuals may not make a single, irrevocable decision at the date of retirement. For example, a person may, upon retirement, roll their DC plan over into an IRA and allow it to grow for 5 more years before taking any withdrawals. Then, several years after taking withdrawals, they may choose to take the rest out in one lump sum. Alternatively, they might leave the money in the employer's account for several years before annuitizing.

This ideal data set does not yet exist. Most long-term panel studies of the elderly, such as the Retirement History Survey, were conducted before defined contribution plans became an important asset class for a large number of households. Other data sets, such as the Survey of 
Consumer Finances, which provide detailed information on assets, fail to have a significant number of retired individuals. These severe data limitations are one important reason that the question of DC plan disposition has not received more attention in the literature.

The Health and Retirement Survey (HRS), fielded by the Institute of Social Research at the University of Michigan, promises to be this ideal data set. The first wave of the study, conducted in 1992, asked detailed financial, health, retirement, and other pertinent questions to a broad cross-section of individuals nearing retirement. Specifically, the HRS target respondents were born between 1931 and 1941, making them approximately 51 to 61 years of age the first interview wave. Spouses of age eligible individuals were also included, so that the age of individual respondent's in the HRS varies over a wider range. Follow-up surveys are being conducted every two years.

While the HRS promises to be the ideal data set for this question in the future, the young age of the sample currently limits researcher's ability to observe actual DC disposition behavior of a large sample over a long period of time after retirement. At this time, only two waves of data have been released in their final form, with a third wave in preliminary release. Most respondents are still employed, and as such have not yet made their actual DC annuitization decision.

As a result, I will use as my primary sample those individuals in wave 1 who are currently employed, and who are covered by at least one defined contribution plan. The HRS questionnaire asks these individuals what they plan to do with their DC account balances when they retire, and it is this question that serves as the basis for this analysis.

The 1992 wave of the HRS contains data on approximately 7500 households. In addition to the household responses to the detailed questionnaire, the HRS has collected Social Security 
Administration data on earnings and benefits histories. This is an important source of data for this project, since Social Security wealth is an important determinant of an individual's demand for additional annuitization. As discussed in Mitchell, Olsen \& Steinmeier (1996), however, the Social Security administrative records are missing for approximately $1 / 3$ of the sample. The primary source of missing records is lack of permission by survey participants to make such a linkage.

Of the remaining households, approximately 950 have defined contribution plans that have a balance of at least $\$ 5000$ and that provide the individual with the choice of taking the payout as an annuity. A $\$ 5000$ premium will purchase an actuarially fair annuity for a 65 year old male that pays approximately $\$ 438$ per year. After losing some additional observations due to missing data, I am left with a final sample size of 869 households. Of these, 140 are individuals, and 729 are married couples.

\subsection{The Dependent Variable}

The HRS asks working individuals a long series of questions about pension coverage. For those individuals who report that they are covered by a defined contribution pension plan, and who report that they have choice over the form of benefits, they are then asked "In what form do you expect to receive benefits?" The questionnaire prompts for lump-sum payment, installments, or monthly pension / annuity. I define the indicator variable "Annuity" to be equal to one if the individual states they will take their DC balances as a monthly pension, and zero otherwise. In cases where the individual has more than one DC plan, Annuity is defined to be equal to 1 if they say they will annuitize any one of the plans.

\section{$\underline{5.3 \text { Calibration of the AEW Measure }}$}

In order to implement the dynamic program to solve for the annuity equivalent wealth, 
one must put some structure on the utility function. I invoke the standard assumption that individuals exhibit constant relative risk aversion:

$$
U\left(C_{t}\right)=\frac{C_{t}^{1-\beta}}{1-\beta}
$$

where $\beta$ is the coefficient of relative risk aversion. Importantly, $1 / \beta$ also measures the elasticity of substitution between consumption at two points in time. One analytical convenience afforded by this choice of utility function is that the problem becomes invariant to the scale of wealth. Therefore, the value of additional annuitization is the same for two individuals if they are alike in all respects except for wealth levels. Importantly, while the level of wealth does not matter in this specification of utility, the composition of wealth between annuitized and non-annuitized assets does matter, and will be discussed below.

I assume that the rate of time preference $\rho$ and the market rate of interest $r$ are both equal to .03 for every household. I assume that annuitized DC balances will purchase a nominal annuity that is declining in real terms by the rate of inflation. Inflation is fixed at $3.2 \%$, which is the historical mean of inflation from 1926-1997 (Ibbotsen Associates, 1998). I will compute the AEW using each individual's expected age of retirement, which has a mean of approximately 63 in my sample.

Extensive simulation work in previous studies has indicated that there are four primary factors that determine an annuity equivalent wealth from annuities within a Yaari life-cycle framework:

(1) Mortality Risk

(2) Risk Aversion

(3) Fraction of Total Wealth that is Pre-Annuitized

(4) Marital Status 
Each of these four factors can be parameterized using data from the HRS.

\subsubsection{Mortality Risk.}

The insurance value of additional annuitization should quite clearly be effected by the degree of mortality risk that an individual faces. For example, an individual who knows their date of death with complete certainty would not be willing to pay any positive amount for an actuarially fair annuity, since there is zero risk to insure against. At the other extreme, an individual with an equal unconditional probability of dying in each of the next 50 years would find annuities quite attractive.

To calibrate differences in survival probabilities, I assign each individual the average population mortality for their birth cohort and gender. I use mortality tables for each birth cohort from the Social Security Administration's Trustees Report (1995). Using a cohort mortality table, which follow a specific birth cohort through time, as opposed to a period mortality table, which looks at the cross-sectional mortality experience at a point in time, is potentially a quite important distinction. Cohort tables incorporate expected future mortality improvements, and thus account for the fact that the probability of a current 50 year old surviving to age 70 , conditional on surviving to age 60 , is not equal to the probability of a current 60 year old living to age 70 .

For most of my calculations, I assume that mortality differences arise only from variation in birth year, gender, and age at retirement. The use of a different mortality table for each birth cohort and gender does capture variation in survival probabilities for two individuals planning to retire at the same age, but in different years. This approach, however, does not allow for potentially important heterogeneity within birth/gender cohorts. Ideally, one would have a survival curve that is specific to each individual and that takes into account differences in life 
expectancies, as well as different slopes in the survival curves. However, obtaining estimates of within cohort heterogeneity that lend themselves to plausible parameterizations in the model is difficult.

As a first step in understanding the effect of mortality differences within cohorts, I will include a separate set of indicator variables for self-reported health status in the equations that I estimate. Using a set of dummy variables to add in health information separately from the AEW measure has the advantage of being easy to interpret, while not requiring that one map health status into a specific change to the trajectory of mortality probabilities. The disadvantage of this approach is that potentially important interactions between health and other determinants of AEW may not be adequately captured. Therefore, in Section 7, I will explore extensions to the basic model that incorporate health and mortality differences directly into the AEW model.

\subsubsection{Risk Aversion}

More risk averse individuals value the longevity insurance aspect of annuities more highly. In order to calibrate this, I make use of a series of questions in the HRS that are designed to elicit one's willingness to take actuarially favorable gambles. The responses to these questions have been studied extensively in Barsky, et al (1997). They showed that measured risk aversion has predictive power for choices over a number of risky behaviors, including the decision to smoke and drink, to buy insurance, and to hold stock, though the incremental predictive power is never very high.

Values of beta were chosen based on answers to the following survey questions:

\footnotetext{
"Suppose that you are the only income earner in the family, and you have a good job guaranteed to give you your current (family) income every year for life. You are given the opportunity to take a new and equally good job, with a 50-50 chance it will double your (family) income and a 50-50 chance that it will cut your (family) income by a third. Would you take the new job?"

If YES:

"Suppose the chances were 50-50 that it would double your (family) income and 50-50 that it would cut it in half. Would you still take the new job?"
} 
If $\mathrm{NO}$ to first question:

"Suppose the chances were 50-50 that it would double your (family) income and 50-50 that it would cut it buy 20 percent. Would you then take the new job?"

Based on responses to these questions, it is possible to divide the sample into four groups that can be ranked in terms of their risk aversion. Furthermore, if we are willing to assume that risk aversion is constant, we are able to put specific bounds on the value of beta that would correspond to these answers.

$\begin{array}{llccc} & & \begin{array}{r}\text { Lower } \\ \text { Bound }\end{array} & \begin{array}{c}\text { Upper } \\ \text { Bound }\end{array} & \begin{array}{l}\text { Value } \\ \text { Used }\end{array} \\ & & & \\ \text { 1. Reject both } 1 / 3 \text { and } 1 / 5 & 3.76 & \infty & \mathbf{5 . 0} \\ \text { 2. Reject } 1 / 3 \text {, accept } 1 / 5 & 2.00 & 3.76 & \mathbf{2 . 9} \\ \text { 3. Accept } 1 / 3 \text {, reject } 1 / 2 & 1.00 & 2.00 & \mathbf{1 . 5} \\ \text { 4. Accept both } 1 / 3 \text { and } 1 / 2 & 0 & 1.00 & \mathbf{0 . 7}\end{array}$

Approximately two-thirds of the sample falls into the most risk averse category. The rest of the sample is evenly split over the remaining three categories.

\subsubsection{Pre-Annuitized Wealth}

The primary insurance value associated with annuitization is that it ensures that the individual's consumption will never fall below the value of the annuity. Since utility is concave in consumption, this means that the first units of insurance are the most valuable. If someone has $0 \%$ of his wealth in annuities, then the first instance of annuitization will be quite valuable because it provides a minimum floor. As additional resources are annuitized, the floor rises, and additional annuitization is valued less.

Let alpha $(\alpha)$ denote the fraction of total wealth that is "pre-annuitized." Specifically, I will define alpha to be the sum of Social Security wealth plus defined benefit pension wealth, divided by total wealth. Total wealth includes all pension wealth, Social Security wealth, all financial assets, and housing. The annuity value of public and private health insurance is 
excluded from both the numerator and denominator. Alpha is computed as of the survey date. The implication of this assumption is that the relative composition of wealth between annuitized and non-annuitized assets will remain constant until retirement.

Due to data limitations, I assume that all DB plans will be taken in an annuity form, and thus ignore the possibility that a small fraction of individuals may not view their DB plan as "pre-annuitized" if it has a lump-sum option. I also assume that for couples, both Social Security and $\mathrm{DB}$ pension provide survivor benefits equal to $2 / 3$ of the benefit to the couple.

\subsubsection{Marital Status}

Married couples have the ability to pool mortality risk, and therefore should value annuities less than individuals (Kotlikoff \& Spivak 1981). In fact, simulations indicate that the calculated annuity equivalent wealth from annuities by couples is on order of half of that by individuals (Brown \& Poterba, 1999). I use marital status at the time of the survey date in 1992 to determine whether AEW is calculated using the individual or joint utility model.

There are additional modeling assumptions that must be made in doing the calculation for couples. The economies of scale parameter $\lambda$ is set in the base case to be equal to 0.6245 . This value was determined based on the work done on "equivalence scales" in household consumption by the National Academy of Sciences (Citro \& Michael 1995). In Section 7, I will also consider the cases of $\lambda=0$ (no economies of scale) and $\lambda=1$ (full economies).

It is also necessary to make an assumption about the "survivorship" decision of couples if they choose to purchase an annuity with their DC accounts. Federal legislation currently requires that individuals who annuitize pension assets must provide at least a 50\% survivor benefit, unless the spouse relinquishes this right, which requires a notarized signature. Holden (1997) has shown that since this requirement was enacted, roughly two-thirds of individuals who 
annuitize accept the default option. Therefore, I assume a Joint and 50\% Survivor annuity is purchased by all couples. This means that the benefit level paid after the death of the first spouse is only half that of the benefit level paid when both spouses are alive.

\section{Specification and Results}

\section{$\underline{6.1 \text { Specification }}$}

The basic model I estimate is:

$$
\operatorname{Pr}\left(\text { Annuity }_{\mathrm{i}}=1\right)=\mathrm{f}\left(\mathrm{AEW}_{\mathrm{i}}, \mathrm{Z}\right)+\varepsilon_{\mathrm{i}}
$$

Annuity is an indicator variable equal to 1 if the individual plans to annuitize, and 0 otherwise. AEW is the utility-based measure of annuity value that has been computed using the

methods described above. $\mathrm{Z}$ is a vector of other covariates, which will be discussed below. I will make the assumption that $\varepsilon_{\mathrm{i}}$ is normally distributed with mean zero, and thus estimate a probit equation using maximum likelihood. This normality assumption is not critical, as a linear probability model or a logistic specification produce nearly identical marginal effects. Specifically, I will estimate:

$$
\begin{aligned}
& \operatorname{Pr}(\text { Annuity }=1)=\int_{-\infty}^{\beta^{\prime} X} \phi(t) d t \\
& \text { where } \beta^{\prime} X=\beta_{0}+\beta_{1} \text { AEW }+\beta_{2}{ }^{\prime} Z
\end{aligned}
$$

\subsection{Baseline Results}

Table 1 provides summary statistics for the variables of interest. Importantly, nearly half the sample reports that they will annuitize their DC plan. These proportions are consistent with the rough measure of DC annuitization that is available through the CPS pension supplement for the actual annuitization decisions of older, retired workers. On average, these households have an annuity equivalent wealth of 1.166 , meaning that they would be indifferent between $\$ 1$ of 
annuitized wealth and $\$ 1.16$ of non-annuitized wealth. The standard deviation is $10.5 \%$, indicating a substantial degree of dispersion in annuity equivalent wealth.

729 of the 869 households $(84 \%)$ consist of a couple, and the rest of individuals. The average household has just over half of their wealth "pre-annuitized" by Social Security and defined benefit pension plans. Another $10 \%$ of wealth is in DC plans, which average $\$ 60,000$ in my sample. These proportions are consistent with the findings of Moore \& Mitchell (1998) who find that the typical household in the HRS has $40 \%$ of their wealth in Social Security, and another $20 \%$ in total pensions (which includes both DB and DC plans). The average age of the sample in 1992 was 55 years old, with an average expected retirement age of 63. In the majority (62\%) of the households, a male holds the (largest) DC plan.

Table 1 also compares the key variables for the group that chooses to annuitize ("annuitants") and the group that does not ("non-annuitants"). This foreshadows many of the result that will follow. First, the calculated annuity equivalent wealth from annuities is a full $2.6 \%$ points higher for annuitants. This appears to be driven by differences in the factors underlying the AEW calculation, including marital status and risk aversion. One can also see that annuitants are less wealthy and have slightly smaller DC balances than non-annuitants.

Table 2 presents the results of a simple bivariate probit equation of annuity choice on the annuity equivalent wealth from the base case. Reported coefficients and standard errors are for the marginal effects of the probit, evaluated at the sample means. Column 1 reports the results for the entire sample of households, including both married and single individuals, for a probit of annuity on AEW. The coefficient on $\partial A$ nnuity/2AEW is 0.61 , and is highly significant. This means that a one percentage point increase in the annuity equivalent wealth leads to a 0.61 
percentage point increase in the probability of stating that one plans to annuitize their DC accounts upon retirement.

In column 2 of table 2, I have added a number of covariates that do not enter directly into the AEW calculation, including indicator variables for race, education, industry, and occupation. Few of these covariates are themselves significant, and they do not significantly alter the coefficient on the AEW measure.

Due to the ability of couples to pool mortality risk, differences in marital status are one important source of variation in the AEW measure. Therefore, if we look separately at individuals and couples, we lose a potentially important source of variation in the AEW measure. Nonetheless, it is instructive to see how well the model performs in these subsets. Columns 3 through 6 in table 2 report these same results separately for single and married individuals. In columns 3 and 4, the results for single individuals indicate that the effect is slightly higher than for the sample as a whole. In column 3, a one-percentage point change in the AEW measure leads to a .75 percentage point increase in the probability of annuitizing. The coefficient is slightly higher (.875) when covariates are added.

The results for married couples only are reported in columns 5 and 6 of Table 2 . We see that the effect of AEW is smaller than that for individuals, indicating an increase in the probability of annuitizing of only 0.56 without covariates, and 0.75 with covariates. Furthermore, the coefficient for married couples is not statistically significant. Thus, the AEW model appears to perform better in the single sample than in the married sample. The calculation for married couples must make a number of assumptions that were not required in the individual model, including an assumption about the nature of household decision making, the extent of economies of scale, and the structure of survival benefits. Given the additional assumptions 
imposed on the model, it is not completely surprising that the individual model performs better than the joint decision making model. This indicates a potential area for further research.

It is interesting to note that the marginal effect of an increase in the AEW measure for both individuals and couples rises when industry, occupation, and education dummies are included, while these covariates appear to have no effect in the pooled sample of individuals and couples. Recall that in the full sample, an additional source of variation is that the AEW for annuities is higher for individuals than for couples, as is the probability of annuitizing. Thus, the inclusion of covariates, while it increases the coefficient of AEW in each sub-sample, is offset by the fact that these covariates soak up some of the variation that is induced by marital status.

\subsection{Allowing for Time Horizon Heterogeneity}

The HRS asks individuals a question that elicits their "time horizon" for financial decision-making. I have defined a variable "myopic" that is equal to 1 if the individual states that her time horizon for financial planning is one year or less, and zero otherwise. The term "myopic" often conveys that people are behaving in a manner that is inconsistent with optimizing behavior, but it need not be the case. For example, an individual may have an illness that leads to a very short life expectancy, thus leading to a rationally short time horizon. Alternatively, individuals may be following a life-cycle model, but with a very high discount rate. $^{2}$

Whatever the reason lying behind the time horizon response, it is clear that it matters for annuitization decisions. Table 3 displays the probit derivatives when the myopic variable is included both directly, and interacted with the annuity equivalent wealth term. Columns 1 and 2

\footnotetext{
${ }^{2}$ There is an experimental module in the HRS designed to elicit information about discount rates by asking about desired slopes of consumption paths. Unfortunately, the question is asked only 200 individuals in the HRS. Within this small group, there is no correlation between the desire for an upward, flat or declining consumption profile, and
} 
again report the results for the pooled sample of single individuals and couples. We can see that the relationship between annuity equivalent wealth and the annuity decision is even stronger for non-myopic individuals. A one percentage point increase in AEW leads to a .94 percentage point increase in the probability of annuitizing for this group. For the "myopic" types, the relationship between AEW and annuity probabilities is actually negative, though this is offset somewhat by a higher intercept term. Once again, these results are not sensitive to the inclusion of other covariates.

Breaking this effect out by singles and married couples, we see that AEW has a significant effect in both populations of non-myopic individuals. For singles, the effect of AEW is 1.18 to 1.41 , and for couples .97 to 1.2 . Importantly, the AEW term is now significant at the .05 level even in the "couples only" specification.

This indicates that it is critical to control for this time horizon heterogeneity. For the $83 \%$ of the population that is non-myopic, there is approximately a one-for-one relationship between annuity equivalent wealth and the probability of annuitizing. There is, however, a nontrivial $17 \%$ of the population whose annuitization behavior is not well explained by a life-cycle model. This supports the methodology used by Diamond (1977), Feldstein (1985), and others who make a distinction between rational life-cyclers and "myopes" when modeling behavior in the presence of Social Security.

\subsection{The Effect of Health Heterogeneity}

The mortality tables used in computing AEW do not take into account differences in health status. Yet health clearly belongs in the model for a number of reasons. First, to the extent that poor health is negatively correlated with survival, this has a direct negative effect on

their response to the time horizon question. This casts doubt on the discount rate interpretation of the time horizon question. 
the present value of a given annuity stream. Second, if individuals in poor health face potentially large medical bills, they may not want to self-impose the liquidity constraint that is implied by annuitizing wealth.

As a first step in addressing this issue, I define a series of indicator variables for selfreported health status. These capture the DC owner's response to a question asking them to rate their health status as "Excellent, Very Good, Good, Fair, or Poor." I treat the "good" response as the omitted category in creating the indicator variables. Table 4 reports the results. In the full sample, the results are insignificant, although they tend to exhibit a plausible pattern. Individuals with excellent, very good, or good health seem more likely to annuitize than those in fair or poor health. The indicator variable for "poor" health is quite large, and statistically significant. It suggests that an individual in poor health is $30 \%$ less likely to annuitize. This negative effect is fairly consistent across individuals and married couples, both with and without covariates. I will explore the role of these health issues further in Section 7.

\section{$\underline{6.5 \text { Wealth Effects }}$}

One implication of the CRRA functional form of utility is that the decision of whether or not to annuitize is independent of the level of wealth. However, there are several reasons to suspect that, other things, equal, wealthier individuals may be less likely to annuitize. First, the risk of “outliving one's resources," which is the primary risk against which annuities provide insurance, is lessened as wealth increases. Second, because one component of total wealth is preexisting annuities, individuals who have more total wealth tend to have more annuities. As a result, pre-existing annuities from Social Security and DB plans may already provide a consumption floor that is fairly high. Third, individuals with substantial wealth may have become wealthy in the first place due to being savvy financial investors. They may believe, 
correctly or incorrectly, that they can earn a return on their investment through careful investment in equities or small businesses, that exceeds the return on an annuity. Fourth, wealthier individuals may be more likely to leave a planned bequest, and thus be less interested in annuitizing.

As the results in Table 4 indicate, there are significantly negative wealth effects. Specifically, in the full sample a $\$ 100,000$ increase in wealth is associated with a .72 to .76 percentage point decrease in the probability of annuitizing. Among individuals only, a $\$ 100,000$ increase in wealth leads to a 1.2 to 1.65 percentage point decrease in annuity probabilities, and among couples, a decrease of .69 to .77 .

\section{$\underline{6.6 \text { Bequests }}$}

The extent to which bequest motives effect marginal economic decisions is an unresolved issue in the economics literature. Research by Bernheim (1991), Laitner \& Juster (1996), and Wilhelm (1996) all point to the existence of operative bequest motives that affect decisions on the margin. On the other hand, work by Hurd $(1987,1989)$ and Brown (1999) finds little support for such a view. Hayashi, Altonji \& Kotlikoff (1996) also reject the implications of an altruistic model.

To test for the effect of bequest motives on the annuity decision, I make use of information on children, as well as responses to questions about the importance of leaving an inheritance. In columns (1) and (2) of Table 5, I include a dummy variable for whether or not the household has any children. The coefficient is actually of the "wrong" sign for a bequest hypothesis, though it is statistically no different from zero. It is important to keep in mind, however, that $94 \%$ of the sample has children, so there is little variation in the sample on this front. Columns 3 and 4 include two separate indicator variables, one for whether any children 
currently live with in the household, and one for whether any children live outside of the household. Again there is no effect.

The HRS also asks individuals a question designed to elicit opinions and plans about inheritances. The question asks:

"Some people think it is important to leave an inheritance to their surviving heirs, while others don't. Do you (both) feel it is very important, somewhat important, or not at all important, (or do you differ in how important it is)?

I use this questions to create two indicator variables for whether the household believes it is very important, or somewhat important. These results are presented in columns 5 and 6 .

According to these results, individuals who believe bequests are very important are less likely to annuitize, but the effect is not significantly different from zero. The coefficient on the indicator for thinking bequests are somewhat important is smaller and even less significant. These results confirm the basic finding that bequest motives are not a significant determinant of marginal annuitization behavior.

\section{Extensions and Robustness}

\subsection{Performance of Model versus "Reduced Form"}

At this point, one may wonder what the tight link with the underlying theory achieves. In other words, why not simply skip the utility maximization model altogether, and instead enter the underlying sources of variation, such as marital status or risk aversion, directly into the probit model. In order to explore this, Table 6 reports results for a probit model of annuity choice in which the underlying "reduced form" variables that provide the variation in the AEW measure are included, along with the AEW measure itself. Because no claim is being made that the AEW measure has any explanatory value in the myopic sample, I restrict this sample to the non- 
myopic group. While not reported in the tables, I have repeated this test using the full sample including the myopic individuals, and found the conclusion from the tests do not change.

The "reduced form" variables include marital status, risk aversion (beta), the fraction of pre-existing annuities (alpha), retirement age, birth year, and gender. I then conduct two likelihood ratio tests. The first one tests the null hypothesis that the "reduced form" coefficients are all jointly zero, conditional on including the AEW variable. Comparing columns 1 and 2 does this. As can be seen, one cannot reject the hypothesis that the reduced form coefficients are jointly zero. This is evidence that the AEW measure is a sufficient statistic for these other variables.

I then run the test the other way, i.e., to test whether the AEW variable is zero once one has controlled for the reduced form. Comparing column 1 to column 3 does this. In this case, I strongly reject the null hypothesis that the AEW measure is zero. This supports the fact that the structure imposed by the life-cycle model has value in predicting annuity decisions that is not captured by the simply including the reduced form variables directly ${ }^{3}$.

\subsection{Accounting for Heterogeneity in Survival Probabilities}

Heterogeneity in survival probabilities is an important source of variation in how households should value the insurance aspect of annuities. Specifically, if an individual has survival prospects that are more favorable than those assumed by the insurance company in pricing the product, her annuity equivalent wealth from the annuity should be greater. In addition, for a given life expectancy, if the uncertainty about mortality is greater, this would also lead one to have a higher valuation for annuities. Up to this point, the impact of heterogeneity in

\footnotetext{
${ }^{3}$ I have also run this test allowing for the continuous reduced form parameters to enter as $2^{\text {nd }}$ order polynomials, as well as including all possible first-order interactions. This results in a total of 24 reduced form coefficients. Even with this full saturation of the model, one still cannot reject the null hypothesis that the reduced form coefficients are
} 
survival probabilities has been explored only by entering health status indicator variables linearly into the probit specification. Ideally, one would incorporate differential mortality information directly into the annuity equivalent wealth calculation, and thus account for the potentially important interactions between mortality risk and the other sources of variation, such as risk aversion.

Unfortunately, it is not possible to observe individual-specific survival probabilities. There are at least two approaches that one can use to approximate these effects however. The first is to use the information on health status, which was described in section 6.4, to adjust the survival curves. The second is a direct question that asks individuals to provide a subjective estimate of the probability that they will survive to age 75 and to age 85 .

The conceptual difficulty with including the self-reported health indicators linearly is, of course, that it too may interact in important ways with other variables to change the AEW. This is, after all, the same reason that risk aversion and the other reduced form variables were "fed through" the utility model. Incorporating health status into the AEW measure is necessarily much more subject to parameterization difficulties. There is no clear justification for assuming that self-reporting poor health leads to a $5 \%$ reduction in mortality as opposed to a $20 \%$ reduction in mortality. In this sense, it differs from the other parameter values used in the AEW measure, which lent themselves more readily to such a parameterization.

As a first step, however, table 7 reports the results for a case in which I parameterized the effect of health in the utility maximization model by multiplying each individual's vector of mortality hazards by a constant. The value of this constant is 1.2 for those in poor health, 1.1 in fair health, 1.0 in good health, .9 in fair health, and .8 in poor health. Columns 1 and 2 report the

all jointly zero. However, one can also no longer reject the null that the AEW term has zero effect, unless the confidence level is .15 or higher. 
results with and without covariates for the full sample. As can be seen, the effect of AEW is slightly smaller than in the case when health differences were not accounted for, but this difference is insignificant. In addition, in column 3, I report the results again when I include the health dummies in the equation, along with the health-adjusted AEW measure. As before, most of the health dummies are insignificant, with the exception of "poor health." Despite the fact that health status was incorporated into the AEW measure through an adjustment in mortality, there is still a large negative effect of nearly a .3 drop in the probability of annuitizing. While this is only one of an infinite number of potential ways to incorporate health status into the AEW calculation directly, it indicates the difficulties of doing so in a way that meaningfully captures the desired variation.

Another approach that is conceptually appealing, but which is fraught with difficult data problems, is to use the HRS questions about subjective survival probabilities to age 75 and to age 85 to adjust the respondent's mortality vector. The shortcomings of these data are discussed extensively in Hurd \& McGarry (1997). I categorize these data problems into several types, including (a) rounding error, due to the fact that the probabilities are reported in increments of 0.1 only, (b) internal inconsistency error, which occurs when an individual reports an unconditional probability of surviving to age 85 that is greater than the unconditional probability of living to age 75, and (c) "extreme value error," which is the phenomenon that a large fraction of the respondents choose probabilities of survival of 0 or 1 . Nearly one-quarter of the total HRS sample chose an age 75 survival probability of 1 , despite the fact that for the average respondent, age 75 is nearly two decades away.

Hurd \& McGarry have shown that, despite the limitations of the data, the subjective survival probabilities behave in aggregate much like actuarial survival probabilities. This finding 
is consistent with earlier findings by Hammermesh (1985) which found that subjective life expectancies are approximately "demographically consistent," in that the average subjective expectation is consistent with actuarial tables. However, in using these data to study a behavioral question such as one's plans for annuitization, the shortcomings of the data appear to overwhelm the advantages.

Setting aside these difficulties for a moment, however, it is possible in principle to use these subjective probabilities as though they represent the actual survival probabilities for the individual. However, since the utility maximization routine requires knowledge about the entire survival curve, and not just two points, the problems with the subjective probabilities are exacerbated. As a starting point, one can simply include the subjective probability as separate variable in the probit regression. I have included it both as a single variable (taking on values between 0 and 1 in increments of 0.1 ) and as individual indicator variables for various combinations of each of the possible values. I have also tried interacting these subjective survival variables with the AEW variable. A few of these specifications are reported in Table 8 . In no case are any of the subjective measures significantly different from zero.

Given the lack of explanatory power in these subjective variables, it comes as no surprise that more formally integrating the subjective probabilities into the AEW calculation does not produce favorable results. In fact, the adapted AEW measure that is calculated by replacing the objective survival probabilities with subjective survival probabilities has no explanatory power for the annuitization decision at all. Of course, this calculation is subject to many additional difficulties, including the need to extrapolate the two-point subjective survival probabilities into a full vector of survival probabilities. One method of doing this conversion is to assume that the ratio of each subjective one-period conditional survival probability to its actuarial counterpart is 
constant from the retirement age to age 74 . Then one can adjust the one period survival probabilities from the appropriate Social Security table for these ages by this constant. The constant is determined so that when the one-period survival probabilities for retirement age through age 74 are multiplied together, they equal the cumulative age 75 subjective probability reported by the individual. A similar method is used to adjust the probabilities between ages 75 and 84 , so that they are consistent with the age 85 subjective probability. Beyond age $85, \mathrm{I}$ assume that the subjective probabilities are equal to the actuarial probabilities. This ensures that the population "dies off" by age 115, the maximum assumed age in the simulations. Table 9 reports the results when these subjective probabilities are used in place of the population probabilities in the calculation of the AEW measure. As suggested above, this adjusted AEW measure has absolutely no explanatory power. Given the difficulties inherent in the construction of individual specific survival curves based on problematic responses, it is not surprising that we get insignificant results out of the model. There are few economic decisions that should be so clearly effected by individual beliefs about survival as the decision to purchase an annuity. Therefore, I view these results as being indicative primarily of the poor quality of the subjective survival data. Future work in this area could be pursued using an econometric framework similar to that used by Hurd, McFadden, and Gan (1996) in the Ahead survey to adjust the reported subjective measures to account for focal point bias.

\section{$\underline{7.3 \text { Alternative Couple's Utility Assumptions }}$}

In my base case, I assumed a degree of economies of scale in consumption for couples that was based on equivalence scales methodology of the National Academy of Sciences. Specifically, I assumed a value of $\lambda$, the "jointness" parameter, of .6245. In order to test the sensitivity of the results to this assumption, table 10 reports results for $\lambda=0$ (no economies of 
scale), and $\lambda=1$ (full economies). In neither of these extreme cases does the model perform as well among couples as the intermediate case assumed throughout. For the case of $\lambda=0$, the resulting coefficients on $\mathrm{AEW}$ is less than half that of the base case, and the significance is lower. For the $\lambda=1$ case, the coefficients are lower than the base case, but higher than the no economies of scale case. These results may be viewed as justifying an "intermediate" jointness assumption, such as that used in the base case.

\section{Conclusions}

This paper has shown that marginal annuity decisions are significantly correlated with the predictions of a simple life-cycle model. I have found that a one-percentage point increase in the annuity equivalent wealth corresponds to a one-percentage point increase in the probability of planning to annuitize. These results support the notion that life-cycle simulation models can provide us with a useful first approximation of household annuity behavior.

Marital status appears to be a particularly important source of underlying variation in the AEW measure and the annuity decision. Married couples are less likely to annuitize than are single individuals, presumably due to the ability to pool mortality risk. These empirical results support the simulation findings of Kotlikoff \& Spivak (1981) and Brown \& Poterba (1999), which demonstrate that couples in a life-cycle model value annuities less than individuals. This is an important result for thinking about the impact of policy changes, such as the introduction of individual accounts as a supplement or partial substitute for the current Social Security system. Analyses that focus on the welfare implications of individuals may miss important variation that arises from differences in the ability to pool mortality risk within larger households, potentially biasing upwards the estimated value of marginal annuitization. 
These results also indicate that the ability of the simple life-cycle model to predict annuity behavior is strongest among individuals. Determining the value of annuitization in a couple's context requires a number of additional assumptions on the structure of the utility function and the structure of survivor benefits. Future work will explore the sensitivity of the results to alternative assumptions in these areas.

While the life-cycle measure of annuity valuation is significantly correlated with expected annuitization, there are several factors that lie "outside" of a simple life cycle model that are important in determining which households annuitize. First, while the life-cycle model appears relevant for the majority of the population, there is a subset of the population with short financial planning horizons that do not behave according to the life cycle model. This is supportive of modeling approaches, such as that used by Diamond (1977) and Feldstein (1985), which account for the existence of both rational life-cyclers and "myopes" in the population.

In addition, these results indicate that individuals in very poor health are significantly less likely to annuitize. This consistent with what a life-cycle model would predict if health status could easily be mapped into a shift in the individual-specific survival curve. However, it has been shown that simple methods for adjusting the survival curve, such as scaling the mortality hazard up or down by a constant based on health status, are insufficient to capture the effect of health on the annuity decision. It is also notable that there is very little difference in the annuitization rates of individuals within the non-poor health sample, i.e., between those reporting fair, good, very good or excellent health.

Finally, this paper casts doubt on the importance of bequest motives in influencing marginal annuity decisions. Neither the presence of children nor the presence of self-reported bequest motives have a significant effect on the annuitization decision. This is in stark contrast 
to the findings of Bernheim (1991), and Laitner \& Juster (1996), that have indicated that bequest motives do influence annuity decisions. These results are supportive of Hurd's (1986) finding that bequest motives do not have a significant effect on the marginal financial behavior of older households. This indicates that a simple life-cycle model with no bequests generates predictions that are consistent with marginal annuitization behavior, and as such, provides a useful first approximation of household behavior. 


\section{REFERENCES}

Abel, Andrew B. "Capital Accumulation and Uncertain Lifetimes with Adverse Selection.” Econometrica 54 (September 1986): 1079-1097.

Abel, Andrew and Mark Warshawsky. "Specification of the Joy of Giving: Insights from Altruism." Review of Economics and Statistics 70 (1988), 145-149.

American Council on Life Insurance. 1997 Life Insurance Fact Book. Washington, D.C.: ACLI, 1997.

Attanasio, Orazio and Hilary W. Hoynes, "Differential Mortality and Wealth Accumulation," NBER Working Paper No. 5126, May 1995.

Auerbach, Alan J., Laurence Kotlikoff, and David Weil, "The Increasing Annuitization of the Elderly: Estimates and Implications for Intergenerational Transfers, Inequality, and National Saving," NBER Working Paper 4182, October 1992.

Bernheim, Douglas D., "How Strong Are Bequest Motives? Evidence Based on Estimates of the Demand for Life Insurance and Annuities," Journal of Political Economy 99 (1991), 899-927.

Bound, John. "Self Reported Objective Measures of Health in Retirement Models." Journal of Human Resources $26(1), 1991.106-138$.

Brown, Jeffrey R., Olivia S. Mitchell, and James M. Poterba. "The Role of Real Annuities and Indexed Bonds in an Individual Accounts Retirement Program.” NBER Working Paper No. 7005, March 1999.

Brown, Jeffrey R. and James M. Poterba. "Joint Life Annuities and Annuity Demand by Married Couples." MIT Mimeo. 1999.

Brown, Jeffrey R. "Are the Elderly Really Overannuitized? New Evidence on Life Insurance and Bequests.” Forthcoming in David Wise, ed., The Economics of Aging, Volume 6. 1999.

Brugiavini, Agar. "Uncertainty Resolution and the Timing of Annuity Purchases," Journal of Public Economics 50 (1993), 31-62.

Citro, Constance F. and Robert T. Michael, editors. Measuring Poverty: A New Approach. Washington D.C.: National Academy of Sciences Press. 1995.

Diamond, Peter A., 1977, "A Framework for Social Security Analysis," Journal of Public Economics 8: 275-298.

Employee Benefit Research Institute, EBRI Databook on Employee Benefits, Washington, D.C., 1995.

Feldstein, Martin. "The Optimal Level of Social Security Benefits." Quarterly Journal of Economics Vol. C No. 2 (May 1985). 305-320.

Frees, Edward W., Jacques Carriere, and Emiliano Valdez. "Annuity Valuation with Dependent Mortality," Journal of Risk and Insurance 63 (1996), 229-261.

Friedman, Benjamin, and Mark Warshawsky. "Annuity Prices and Saving Behavior in the United States". In Z. Bodie, J. Shoven, and D. Wise, eds., Pensions in the US Economy. Chicago: University of Chicago Press, 1988. Pp. 53-77.

Friedman, Benjamin, and Mark Warshawsky. "The Cost of Annuities: Implications for Saving Behavior and Bequests.” Quarterly Journal of Economics 105 (1, February 1990): 135-154 
Hammermesh, Daniel S. 1985. "Expectations, Life Expectancy, and Economic Behavior.” Quarterly Journal of Economics 100(2) 389-408.

Hayashi, Fumio, Joseph Altonji, and Laurence Kotlikoff. "Risk Sharing Between and Within Families." Econometrica. 64(2) March 1996. 261-94

Holden, Karen. "Women as Widows under a Reformed Social Security System," in Prospects for Social Security Reform (Philadelphia: Pension Research Council, The Wharton School, University of Pennsylvania.). 1997.

Hubbard, R. Glenn. "Uncertain Lifetimes, Pensions, and Individual Saving." In Z. Bodie, J. Shoven, and D. Wise, eds., Issues in Pension Economics. Chicago: University of Chicago Press, 1987. Pp. 175-206.

Hurd, Michael D., Daniel McFadden and Li Gan. "Subjective Survival Curves and Life Cycle Behavior.” Presented at NBER Summer Institute. Version 7/12/96.

Hurd, Michael D. “Mortality Risk and Bequests.” Econometrica 57 (4) 1989 pp779-813.

Hurd, Michael D. and Kathleen McGarry. "Evaluation of the Subjective Probabilities of Survival." Journal of Human Resources 30 Supplement 1995 S268-S292.

Hurd, Michael D. "Savings of the Elderly and Desired Bequests." American Economic Review 77 (3) 1987 pp. 298-312.

Hurd, Michael D. “The Marginal Value of Social Security.” NBER Working Paper 2411. 1987.

Ibbotson Associates. Stocks Bonds Bills and Inflation: 1998 Yearbook. Chicago: Ibbotson Associates.

Jousten, Alain. "Lifecycle Modeling of Bequests and Their Impact on Annuity Valuation." Mimeo, MIT Economics Department, 1997.

Johansen, R. "Review of Adequacy of 1983 Individual Annuity Mortality Table," Transactions of the Society of Actuaries, 47, 1996, $101-23$.

Kotlikoff, Laurence J. and Avia Spivak. "The Family as an Incomplete Annuities Market." Journal of Political Economy 89 (April 1981): 372-391.

Kotlikoff, Laurence J. and Lawrence Summers. "The Role of Intergenerational Transfers in Aggregate Capital Accumulation." Journal of Political Economy 89 (4) 1981. 706-32.

Laitner, John and F. Thomas Juster, 1996, "New Evidence on Altruism: A Study of TIAA-CREF Retirees," American Economic Review 86: 893-908.

LIMRA International. "Immediate Annuities.” Product Design Series. Hartford: LIMRA International. 1998.

LIMRA International. "The 1995 Individual Annuity Market - Sales and Assets." Annuity Research. Hartford: LIMRA International. July 1996.

McGill, Dan M., Kyle N. Brown, John J. Haley, and Sylvester J. Schieber, Fundamentals of Private Pensions, $7^{\text {th }}$ ed., Pension Research Council, University of Pennsylvania, 1996.

Milevsky, Moshe A. "Optimal Asset Allocation Towards the End of the Life Cycle: To Annuitize or Not to Annuitize," Journal of Risk and Insurance (forthcoming).

Mitchell, Olivia S., James M. Poterba, Mark Warshawsky, and Jeffrey R. Brown. “New Evidence on the Money's Worth of Individual Annuities.” American Economic Review (forthcoming). 1999. 
Mitchell, Olivia S., Jan Olson and Thomas Steinmeier, "Construction of the Earnings and Benefits File (EBF) for Use with the Health and Retirement Survey.” NBER Working Paper \#5707. August 1996.

Moore, James F. and Olivia S. Mitchell. "Projected Retirement Wealth and Savings Adequacy in the Health and Retirement Study.” Working Paper, Pension Research Council, Wharton School, University of Pennsylvania. 1998.

Pappas, G., et al., "The Increasing Disparity in Mortality Between Socioeconomic Groups in the United States, 1960 and 1986," New England Journal of Medicine 329 (2), July 8 1993, 103-109.

Poterba, James M., Steven F. Venti, and David A. Wise. "401(k) Plans and Future Patterns of Retirement Saving." American Economic Review. v88 n2 May 1998, pp. 179-84

Rothschild, Michael, and Joseph Stiglitz, "Equilibrium in Competitive Insurance Markets: An Essay on the Economics of Imperfect Information," Quarterly Journal of Economics, 90, November 1976, 629 - 49.

Thaler, Richard, "Savings, Fungibility and Mental Accounts," Journal of Economic Perspectives, (4) 193-205 (1990)

Warshawsky, Mark, "Private Annuity Markets in the United States," Journal of Risk and Insurance 55(3), September 1988, 518-528.

Wilhelm, Mark, 1996, "Bequest Behavior and the Effect of Heirs' Earnings: Testing the Altruistic Model of Bequests," American Economic Review 86: 874-892.

Yaari, Menahem E., "Uncertain Lifetime, Life Insurance, and the Theory of the Consumer," Review of Economic Studies, 32: 137-150. 1965 
</ref_section> 
Table 1

Summary Statistics

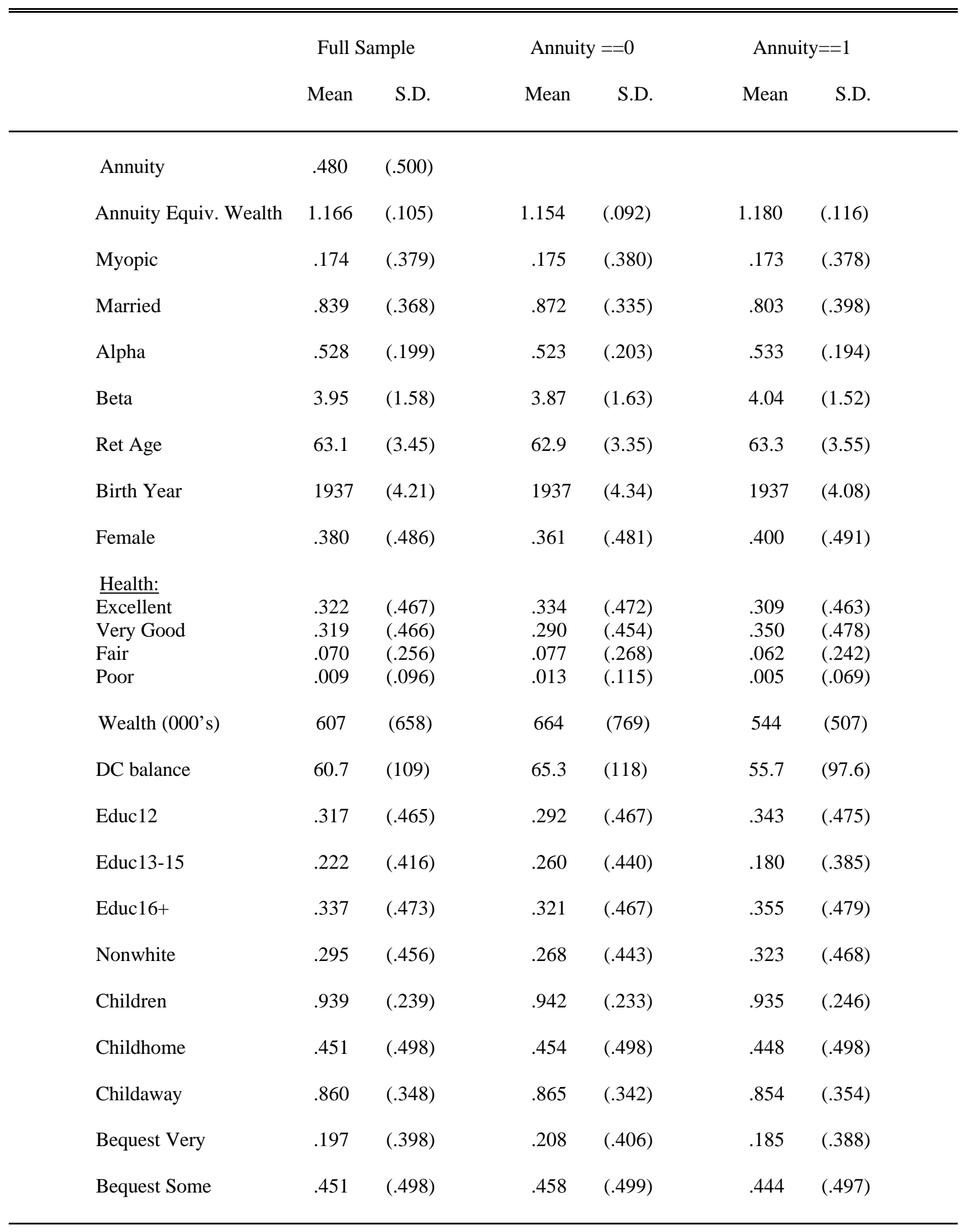


Table 2

Effect of Calculated Annuity Equivalent Wealth on Intended Annuitization Base Case Probit Results

\begin{tabular}{|c|c|c|c|c|c|c|}
\hline & (1) & (2) & (3) & (4) & (5) & (6) \\
\hline Sample & Full & Full & Individuals & Individuals & Couples & Couples \\
\hline AEW & $\begin{array}{c}.6089 \\
(.1650)\end{array}$ & $\begin{array}{l}.6547 \\
(.1990)\end{array}$ & $\begin{array}{l}.7505 \\
(.3429)\end{array}$ & $\begin{array}{l}.8751 \\
(.4027)\end{array}$ & $\begin{array}{c}.5575 \\
(.4183)\end{array}$ & $\begin{array}{l}.7477 \\
(.4490)\end{array}$ \\
\hline Educ12 & & $\begin{array}{l}.0563 \\
(.0613)\end{array}$ & & $\begin{array}{l}.1835 \\
(.1412)\end{array}$ & & $\begin{array}{l}.0285 \\
(.0681)\end{array}$ \\
\hline Educ13-15 & & $\begin{array}{l}-.0768 \\
(.0653)\end{array}$ & & $\begin{array}{l}.0503 \\
(.1597)\end{array}$ & & $\begin{array}{l}-.1100 \\
(.0719)\end{array}$ \\
\hline Educ16+ & & $\begin{array}{c}.0212 \\
(.0675)\end{array}$ & & $\begin{array}{l}.1582 \\
(.1622)\end{array}$ & & $\begin{array}{l}-.0091 \\
(.0751)\end{array}$ \\
\hline NonWhite & & $\begin{array}{l}-.0176 \\
(.0460)\end{array}$ & & $*$ & & $\begin{array}{l}-.0138 \\
(.0544)\end{array}$ \\
\hline Industry Dummies & No & Yes & No & Yes & No & Yes \\
\hline Occupation Dummies & No & Yes & No & Yes & No & Yes \\
\hline Log Likelihood & -594.7 & -571.2 & -92.5 & -84.7 & -502.0 & -479.8 \\
\hline \# Obs. & 869 & 869 & 140 & 140 & 729 & 729 \\
\hline
\end{tabular}

Notes: $\quad$ AEW is the "Annuity Equivalent Wealth" as described in the text.

Dependent variable is indicator variable "Annuity," which equals one if the household expects to annuitize their defined contribution plan, and zero otherwise. Reported coefficients are the marginal effects of the probit evaluated at the sample means. Standard errors of the marginal effects are reported in parentheses.

* NonWhite dropped (column 4) due to collinearity with Industry, Occupation and Education 
Table 3

\section{Impact of Time Horizon Heterogeneity on Intended Annuitization}

\begin{tabular}{|c|c|c|c|c|c|c|}
\hline & (1) & (2) & (3) & (4) & (5) & (6) \\
\hline Sample & Full & Full & Individuals & Individuals & Couples & Couples \\
\hline AEW & $\begin{array}{l}.9418 \\
(.1911)\end{array}$ & $\begin{array}{l}.9948 \\
(.2220)\end{array}$ & $\begin{array}{c}1.181 \\
(.3878)\end{array}$ & $\begin{array}{l}1.407 \\
(.4490)\end{array}$ & $\begin{array}{l}.9690 \\
(.4646)\end{array}$ & $\begin{array}{l}1.197 \\
(.4942)\end{array}$ \\
\hline Myopic & $\begin{array}{l}.2628 \\
(.0765)\end{array}$ & $\begin{array}{l}.2722 \\
(.0802)\end{array}$ & $\begin{array}{l}.5897 \\
(.1402)\end{array}$ & $\begin{array}{c}.6112 \\
(.1493)\end{array}$ & $\begin{array}{l}.3016 \\
(.1300)\end{array}$ & $\begin{array}{l}.3376 \\
(.1306)\end{array}$ \\
\hline Myopic*AEW & $\begin{array}{l}-1.655 \\
(.4355)\end{array}$ & $\begin{array}{l}-1.752 \\
(.4567)\end{array}$ & $\begin{array}{l}-3.079 \\
(1.029)\end{array}$ & $\begin{array}{l}-3.569 \\
(1.214)\end{array}$ & $\begin{array}{l}-2.175 \\
(1.128)\end{array}$ & $\begin{array}{l}-2.523 \\
(1.171)\end{array}$ \\
\hline Education Dummies & No & Yes & No & Yes & No & Yes \\
\hline Industry Dummies & No & Yes & No & Yes & No & Yes \\
\hline Occupation Dummies & No & Yes & No & Yes & No & Yes \\
\hline Log Likelihood & -587.1 & .563 .3 & -85.63 & -76.71 & -499.7 & -477.2 \\
\hline \# Obs. & 869 & 869 & 140 & 140 & 729 & 729 \\
\hline
\end{tabular}

Notes: $\quad$ AEW is the "Annuity Equivalent Wealth" as described in the text.

Dependent variable is indicator variable "Annuity," which equals one if the household expects to annuitize their defined contribution plan, and zero otherwise. Reported coefficients are the marginal effects of the probit evaluated at the sample means. Standard errors of the marginal effects are reported in parentheses. 
Table 4

Health and Wealth Effects on the Intended Annuitization

\begin{tabular}{|c|c|c|c|c|c|c|}
\hline & (1) & (2) & (3) & (4) & (5) & (6) \\
\hline Sample & Full & Full & Individuals & Individuals & Couples & Couples \\
\hline AEW & $\begin{array}{l}.9441 \\
(.1932)\end{array}$ & $\begin{array}{l}1.019 \\
(.2244)\end{array}$ & $\begin{array}{l}1.249 \\
(.3946)\end{array}$ & $\begin{array}{l}1.484 \\
(.4589)\end{array}$ & $\begin{array}{l}1.208 \\
(.4785)\end{array}$ & $\begin{array}{l}1.360 \\
(.5076)\end{array}$ \\
\hline Myopic & $\begin{array}{l}.2717 \\
(.0774)\end{array}$ & $\begin{array}{l}.2828 \\
(.0806)\end{array}$ & $\begin{array}{l}.5823 \\
(.1496)\end{array}$ & $\begin{array}{l}.6065 \\
(.1580)\end{array}$ & $\begin{array}{l}.3266 \\
(.1296)\end{array}$ & $\begin{array}{l}.3625 \\
(.1286)\end{array}$ \\
\hline Myopic*AEW & $\begin{array}{l}-1.723 \\
(.4460)\end{array}$ & $\begin{array}{l}-1.814 \\
(.4670)\end{array}$ & $\begin{array}{l}-3.040 \\
(1.076)\end{array}$ & $\begin{array}{l}-3.548 \\
(1.258)\end{array}$ & $\begin{array}{l}-2.373 \\
(1.158)\end{array}$ & $\begin{array}{l}-2.376 \\
(1.195)\end{array}$ \\
\hline Health: Excellent & $\begin{array}{l}.0070 \\
(.0448)\end{array}$ & $\begin{array}{l}-.0036 \\
(.0470)\end{array}$ & $\begin{array}{l}.0833 \\
(.1164)\end{array}$ & $\begin{array}{l}.1347 \\
(.1343)\end{array}$ & $\begin{array}{l}-.0023 \\
(.0480)\end{array}$ & $\begin{array}{l}-.0210 \\
(.0503)\end{array}$ \\
\hline Health: Very Good & $\begin{array}{l}.0632 \\
(.0447)\end{array}$ & $\begin{array}{l}.0613 \\
(.0468)\end{array}$ & $\begin{array}{l}.1875 \\
(.1087)\end{array}$ & $\begin{array}{l}.2156 \\
(.1278)\end{array}$ & $\begin{array}{l}.0450 \\
(.0485)\end{array}$ & $\begin{array}{l}.0363 \\
(.0507)\end{array}$ \\
\hline Health: Fair & $\begin{array}{l}-.0365 \\
(.0730)\end{array}$ & $\begin{array}{l}-.0636 \\
(.0765)\end{array}$ & $\begin{array}{l}.2411 \\
(.1537)\end{array}$ & $\begin{array}{l}.3472 \\
(.1234)\end{array}$ & $\begin{array}{l}-.0710 \\
(.0767)\end{array}$ & $\begin{array}{l}-.1287 \\
(.0790)\end{array}$ \\
\hline Health: Poor & $\begin{array}{l}-.3077 \\
(.1362)\end{array}$ & $\begin{array}{l}-.2880 \\
(.1469)\end{array}$ & $\begin{array}{l}-.2788 \\
(.2958)\end{array}$ & $\begin{array}{l}-.1178 \\
(.3787)\end{array}$ & $\begin{array}{l}-.2794 \\
(.1902)\end{array}$ & $\begin{array}{l}-.2734 \\
(.1977)\end{array}$ \\
\hline Wealth $(100,000)$ & $\begin{array}{l}-.0076 \\
(.0029)\end{array}$ & $\begin{array}{l}-.0072 \\
(.0032)\end{array}$ & $\begin{array}{l}-.0122 \\
(.0112)\end{array}$ & $\begin{array}{l}-.0165 \\
(.0132)\end{array}$ & $\begin{array}{l}-.0077 \\
(.0031)\end{array}$ & $\begin{array}{l}-.0069 \\
(.0034)\end{array}$ \\
\hline Education Dummies & No & Yes & No & Yes & No & Yes \\
\hline Industry Dummies & No & Yes & No & Yes & No & Yes \\
\hline Occupation Dummies & No & Yes & No & Yes & No & Yes \\
\hline Log Likelihood & -580.1 & -557.0 & -82.6 & -73.8 & -494.6 & -471.8 \\
\hline \# Obs. & 869 & 869 & 140 & 140 & 729 & 729 \\
\hline
\end{tabular}

Notes: $\quad$ AEW is the "Annuity Equivalent Wealth" as described in the text.

Dependent variable is indicator variable "Annuity," which equals one if the household expects to annuitize their defined contribution plan, and zero otherwise. Reported coefficients are the marginal effects of the probit evaluated at the sample means. Standard errors of the marginal effects are reported in parentheses. 
Table 5

Effect of Bequest Motives on Intended Annuitization

\begin{tabular}{|c|c|c|c|c|c|c|}
\hline & (1) & (2) & (3) & (4) & (5) & (6) \\
\hline Sample & Full & Full & Full & Full & Full & Full \\
\hline AEW & $\begin{array}{l}.9946 \\
(.2024)\end{array}$ & $\begin{array}{l}1.080 \\
(.2313)\end{array}$ & $\begin{array}{l}.9659 \\
(.1976)\end{array}$ & $\begin{array}{l}1.106 \\
(.2284)\end{array}$ & $\begin{array}{l}.9539 \\
(.1937)\end{array}$ & $\begin{array}{l}1.018 \\
(.2248)\end{array}$ \\
\hline Myopic & $\begin{array}{l}.2762 \\
(.0771)\end{array}$ & $\begin{array}{l}.2898 \\
(.0801)\end{array}$ & $\begin{array}{l}.2729 \\
(.0773)\end{array}$ & $\begin{array}{l}.2864 \\
(.0803)\end{array}$ & $\begin{array}{l}.2719 \\
(.0776)\end{array}$ & $\begin{array}{l}.2838 \\
(.0808)\end{array}$ \\
\hline Myopic*AEW & $\begin{array}{l}-1.748 \\
(.4458)\end{array}$ & $\begin{array}{l}-1.851 \\
(.4666)\end{array}$ & $\begin{array}{l}-1.730 \\
(.4457)\end{array}$ & $\begin{array}{l}-1.831 \\
(.4661)\end{array}$ & $\begin{array}{l}-1.713 \\
(.4473)\end{array}$ & $\begin{array}{l}-1.808 \\
(.4694)\end{array}$ \\
\hline Wealth $(100,000)$ & $\begin{array}{l}-.0076 \\
(.0029)\end{array}$ & $\begin{array}{l}-.0073 \\
(.0032)\end{array}$ & $\begin{array}{l}-.0077 \\
(.0029)\end{array}$ & $\begin{array}{l}-.0074 \\
(.0032)\end{array}$ & $\begin{array}{l}-.0075 \\
(.0029)\end{array}$ & $\begin{array}{l}-.0070 \\
(.0032)\end{array}$ \\
\hline Children & $\begin{array}{l}.0669 \\
(.0752)\end{array}$ & $\begin{array}{l}.0915 \\
(.0774)\end{array}$ & & & & \\
\hline ChildHome & & & $\begin{array}{l}.0245 \\
(.0354)\end{array}$ & $\begin{array}{l}.0398 \\
(.0368)\end{array}$ & & \\
\hline ChildAway & & & $\begin{array}{l}.0045 \\
(.0512)\end{array}$ & $\begin{array}{l}.0175 \\
(.0533)\end{array}$ & & \\
\hline BequestVery & & & & & $\begin{array}{l}-.0051 \\
(.0487)\end{array}$ & $\begin{array}{l}-.0071 \\
(.0505)\end{array}$ \\
\hline BequestSome & & & & & $\begin{array}{l}-.0340 \\
(.0386)\end{array}$ & $\begin{array}{l}-.0358 \\
(.0397)\end{array}$ \\
\hline $\begin{array}{l}\text { Health Dummies } \\
\text { Education Dummies } \\
\text { Industry Dummies } \\
\text { Occupation Dummies }\end{array}$ & $\begin{array}{l}\text { Yes } \\
\text { No } \\
\text { No } \\
\text { No }\end{array}$ & $\begin{array}{l}\text { Yes } \\
\text { Yes } \\
\text { Yes } \\
\text { Yes }\end{array}$ & $\begin{array}{l}\text { Yes } \\
\text { No } \\
\text { No } \\
\text { No }\end{array}$ & $\begin{array}{l}\text { Yes } \\
\text { Yes } \\
\text { Yes } \\
\text { Yes }\end{array}$ & $\begin{array}{l}\text { Yes } \\
\text { No } \\
\text { No } \\
\text { No }\end{array}$ & $\begin{array}{l}\text { Yes } \\
\text { Yes } \\
\text { Yes } \\
\text { Yes }\end{array}$ \\
\hline Log Likelihood & -579.8 & -556.3 & -579.9 & -556.4 & -579.4 & -555.8 \\
\hline \# Obs. & 869 & 869 & 869 & 869 & 869 & 869 \\
\hline
\end{tabular}

Notes: $\quad$ AEW is the "Annuity Equivalent Wealth" as described in the text.

Dependent variable is indicator variable "Annuity," which equals one if the household expects to annuitize their defined contribution plan, and zero otherwise. Reported coefficients are the marginal effects of the probit evaluated at the sample means. Standard errors of the marginal effects are reported in parentheses. 
Table 6

Comparing the Calculated AEW with Reduced Form Specification

Non-Myopic Individuals and Couples

(1)

(2)

(3)

\begin{tabular}{lccc}
\hline & & & \\
AEW & 1.191 & .9419 & \\
Married & $.4560)$ & $(.1911)$ & -.1864 \\
& .0802 & $.0531)$ \\
Alpha & $(.1151)$ & .0397 \\
& .1979 & $(.0969)$ \\
Gamma & $(.1143)$ & .0303 \\
& .0128 & $(.0120)$ \\
RetAge & $(.0137)$ & .0148 \\
& .0035 & $(.0059)$ \\
BirthYear & $(.0073)$ & .0044 \\
& .0017 & $(.0049)$ \\
Female & $(.0050)$ & .0253 \\
& .0232 & & $(.0412)$ \\
\hline Log Likelihood & $(.0415)$ & & -484.5 \\
\# Obs. & -481.1 & -484.3 & 718 \\
\hline
\end{tabular}

Notes: $\quad$ AEW is the "Annuity Equivalent Wealth" as described in the text.

Dependent variable is indicator variable "Annuity," which equals one if the household expects to annuitize their defined contribution plan, and zero otherwise. Reported coefficients are the marginal effects of the probit evaluated at the sample means. Standard errors of the marginal effects are reported in parentheses.

\section{Likelihood Ratio Tests:}

$\begin{array}{lccccc} & \begin{array}{c}\text { Columns } \\ \text { Tested }\end{array} & -2 \ln \left(\lambda_{\mathrm{U}} \lambda_{\mathrm{R}}\right) & \text { d.f. } & \begin{array}{c}\chi^{2} \\ \text { P-val. }\end{array} & \text { Reject? } \\ \begin{array}{l}\mathrm{H}_{0}: \beta \text { for Reduced } \\ \text { Form Jointly }=0\end{array} & \text { (1) vs. (2) } & 6.40 & 6 & .3799 & \text { No } \\ \mathrm{H}_{0}: \beta \text { for AEW }=0 & \text { (1) vs. (3) } & 6.88 & 1 & .0087 & \text { Yes }\end{array}$




\section{Table 7 \\ Incorporating Health into AEW Calculation \\ Full Sample}

(1)

(2)

(3)

\begin{tabular}{|c|c|c|c|}
\hline $\begin{array}{r}\text { AEW (w/ health } \\
\text { adjustment) }\end{array}$ & $\begin{array}{l}.8624 \\
(.1854)\end{array}$ & $\begin{array}{l}.9145 \\
(.2139)\end{array}$ & $\begin{array}{l}.9194 \\
(.2178)\end{array}$ \\
\hline Myopic & $\begin{array}{l}.2803 \\
(.0778)\end{array}$ & $\begin{array}{l}.2835 \\
(.0823)\end{array}$ & $\begin{array}{l}.2982 \\
(.0825)\end{array}$ \\
\hline Myopic*AEW & $\begin{array}{l}-1.618 \\
(.4209)\end{array}$ & $\begin{array}{l}-1.686 \\
(.4428)\end{array}$ & $\begin{array}{l}-1.770 \\
(.4532)\end{array}$ \\
\hline Wealth $(100,000)$ & & $\begin{array}{l}-.0075 \\
(.0032)\end{array}$ & $\begin{array}{l}-.0073 \\
(.0032)\end{array}$ \\
\hline Health: Excellent & & & $\begin{array}{l}-.0149 \\
(.0473)\end{array}$ \\
\hline Health: Very Good & & & $\begin{array}{l}.0607 \\
(.0468)\end{array}$ \\
\hline Health: Fair & & & $\begin{array}{l}-.0511 \\
(.0771)\end{array}$ \\
\hline Health: Poor & & & $\begin{array}{l}-.2831 \\
(.1483)\end{array}$ \\
\hline Education Dummies & No & Yes & Yes \\
\hline Industry Dummies & No & Yes & Yes \\
\hline Occupation Dummies & No & Yes & Yes \\
\hline Log Likelihood & -588.3 & -561.5 & -558.1 \\
\hline \# Obs. & 869 & 869 & 869 \\
\hline
\end{tabular}

Notes: $\quad$ AEW is the "Annuity Equivalent Wealth" as described in the text. In this table, the AEW calculation incorporates a mortality adjustment based on respondent's self-reported health status as described in text.

Dependent variable is indicator variable "Annuity," which equals one if the household expects to annuitize their defined contribution plan, and zero otherwise. Reported coefficients are the marginal effects of the probit evaluated at the sample means. Standard errors of the marginal effects are reported in parentheses. 
Table 8

The Impact of Subjective Survival Probabilities

Full Sample

(1)

(2)

(3)

\begin{tabular}{|c|c|c|c|}
\hline AEW & $\begin{array}{l}1.036 \\
(.2260)\end{array}$ & $\begin{array}{l}.7933 \\
(.4795)\end{array}$ & $\begin{array}{l}1.008 \\
(.2250)\end{array}$ \\
\hline $\begin{array}{c}\text { Subjective Survival } \\
\text { Probability (SSP) }\end{array}$ & $\begin{array}{l}-.0611 \\
(.0725)\end{array}$ & $\begin{array}{l}-.1219 \\
(.1285)\end{array}$ & \\
\hline $\mathrm{SSP} * \mathrm{AEW}$ & & $\begin{array}{l}.3761 \\
(.6556)\end{array}$ & \\
\hline $\mathrm{SSP}<=.2$ indicator & & & $\begin{array}{l}-.1075 \\
(.0885)\end{array}$ \\
\hline $\mathrm{SSP}>=.8$ indicator & & & $\begin{array}{l}-.0283 \\
(.0401)\end{array}$ \\
\hline Myopic & $\begin{array}{l}.2910 \\
(.0805)\end{array}$ & $\begin{array}{l}.2925 \\
(.0804)\end{array}$ & $\begin{array}{l}.2761 \\
(.0812)\end{array}$ \\
\hline Myopic*AEW & $\begin{array}{l}-1.850 \\
(.4723)\end{array}$ & $\begin{array}{l}-1.855 \\
(.4715)\end{array}$ & $\begin{array}{l}-1.770 \\
(.4692)\end{array}$ \\
\hline Wealth $(100,000)$ & $\begin{array}{l}-.0076 \\
(.0033)\end{array}$ & $\begin{array}{l}-.0076 \\
(.0033)\end{array}$ & $\begin{array}{l}-.0071 \\
(.0032)\end{array}$ \\
\hline Health Dummies & Yes & Yes & Yes \\
\hline Education Dummies & Yes & Yes & Yes \\
\hline Industry Dummies & Yes & Yes & Yes \\
\hline Occupation Dummies & Yes & Yes & Yes \\
\hline Log Likelihood & -551.8 & -551.6 & -554.9 \\
\hline \# Obs. & 869 & 869 & 869 \\
\hline
\end{tabular}

Notes: $\quad$ AEW is the "Annuity Equivalent Wealth" as described in the text.

Dependent variable is indicator variable "Annuity," which equals one if the household expects to annuitize their defined contribution plan, and zero otherwise. Reported coefficients are the marginal effects of the probit evaluated at the sample means. Standard errors of the marginal effects are reported in parentheses. 
Table 9

Incorporating Subjective Mortality into AEW Measure

Full Sample

(1)

(2)

(3)

\begin{tabular}{lccc}
\hline & & & \\
AEW (w/ subjective & -.0687 & -.0475 & -.0860 \\
$\quad$ mortality adj.) & $(.1044)$ & $.1156)$ & $(.1214)$ \\
Myopic & & .0172 & .0080 \\
& & $(.0649)$ & $(.0696)$ \\
Myopic*AEW & & -.1137 & -.1022 \\
Wealth (100,000) & & $.2698)$ & $(.2839)$ \\
Health Dummies & No & & -.0076 \\
Education Dummies & No & No & Yes \\
Industry Dummies & No & No & Yes \\
Occupation Dummies & No & No & Yes \\
& & No & Yes \\
\hline Log Likelihood & -601.4 & & -570.9 \\
\# Obs. & 869 & -601.3 & 869 \\
\hline
\end{tabular}

Notes: Dependent variable is indicator variable "Annuity," which equals one if the household expects to annuitize their defined contribution plan, and zero otherwise. Reported coefficients are the marginal effects of the probit evaluated at the sample means. Standard errors of the marginal effects are reported in parentheses.

AEW calculation incorporates a mortality adjustment based on respondent's subjective survival probabilities as described in the text. 
Table 10

Alternative Assumptions About Within-Couple Economies of Scale $\lambda=$ Within Couples Economies of Scale Parameter

\begin{tabular}{lcccccc}
\hline \hline & & & & & & \\
& & $(1)$ & $(3)$ & $(4)$ & $(5)$ & $(6)$ \\
& $\lambda=.6245$ & $\lambda=.6245$ & $\lambda=0$ & $\lambda=0$ & $\lambda=1$ & $\lambda=1$ \\
& & & & & & \\
AEW & .5575 & .9690 & .2511 & .4220 & .4675 & .7026 \\
& $(.4183)$ & $(.4646)$ & $(.2413)$ & $(.2642)$ & $(.4413)$ & $(.4899)$ \\
Myopic & & .3016 & & .2508 & & .1343 \\
& & $(.1300)$ & & $(.1373)$ & & $(.1078)$ \\
Myopic*AEW & & -2.175 & & -1.030 & & -1.092 \\
& & $(1.128)$ & & $(.6677)$ & & $(1.169)$ \\
& & & & & & \\
\hline Log Likelihood & -502.0 & -499.7 & -502.4 & -500.9 & -502.4 & -501.5 \\
\# Obs. & 729 & 729 & 729 & 729 & 729 & 729 \\
\hline
\end{tabular}

Notes: Dependent variable is indicator variable "Annuity," which equals one if the household expects to annuitize their defined contribution plan, and zero otherwise. Reported coefficients are the marginal effects of the probit evaluated at the sample means. Standard errors of the marginal effects are reported in parentheses. 